\title{
Immobilization and nutrient uptake in 'early isabella' grapevines grafted on different rootstocks in organic management
}

\author{
Extração e imobilização de nutrientes em videiras 'isabel precoce' \\ enxertadas em diferentes porta-enxertos e cultivada em sistema \\ orgânico
}

\author{
Alessandro Jefferson Sato ${ }^{1 *}$; Renato Vasconcelos Botelho'; ${ }^{2}$ Doglas Broetto ${ }^{3}$; \\ Thiago Marchi ${ }^{4}$; Ires Cristina Ribeiro Oliari ${ }^{5}$
}

\begin{abstract}
This study evaluated the immobilization and nutrient uptake in an experimental organic vineyard of 'Early Isabella' grapevines in the Midwestern region of Parana State, Brazil. The experimental design was implemented in randomized blocks with two different rootstocks 'Paulsen 1103' and 'VR 043-43' along with four replications and three plants per plot. Five years after planting, one plant per plot was completely removed from the soil and then subdivided into root, stem and canes. The remaining plants in the area were managed until harvest. The sectioned parts and clusters were dried in a forced air oven at $65^{\circ} \mathrm{C}$. The dry mass was subsequently determined and mineral analyses were performed. The amounts of nutrient uptake immobilized by 'Early Isabella' grapevines with yields between 9.9 and 16.6 $\mathrm{t} \mathrm{ha}^{-1}$ were $64.9,19.0,156.9,45.8$ and $12.7 \mathrm{~kg} \mathrm{ha}^{-1}$ for $\mathrm{N}, \mathrm{P}, \mathrm{K}, \mathrm{Ca}, \mathrm{Mg}$, respectively, when grafted on Paulsen '1103' and 112.8, 29.3, 260.8, 82.3 and $26.0 \mathrm{~kg} \mathrm{ha}^{-1}$, respectively, when grafted on 'VR 043-43'. Key words: Mineral nutrition. Vitis labrusca. Paulsen '1103' and 'VR 043-43'.
\end{abstract}

Resumo

O objetivo do trabalho foi avaliar a imobilização e extração de macronutrientes em um vinhedo experimental de cultivo orgânico de videiras cv. Isabel Precoce na região Centro-Oeste do Paraná. O delineamento experimental foi em blocos casualizados, com dois tratamentos (porta-enxertos: Paulsen '1103' e 'VR 043-43'), quatro repetições e três plantas por parcela. Cinco anos após o plantio, uma planta por parcela foi totalmente removida do solo, sendo que posteriormente as videiras foram subdivididas em três partes: raiz, caule e ramos do ano. A partir das plantas remanescentes no campo, realizou-se a colheita dos cachos. Para as avaliações, as plantas e os cachos foram secos em estufa de ar forçado a $65^{\circ} \mathrm{C}$. Posteriormente, determinou-se a massa seca e se realizaram análises do teor dos macronutrientes dos tecidos vegetais Pelos resultados obtidos, verificou-se que as quantidades de nutrientes imobilizadas e exportadas pela videira cv. Isabel Precoce com produtividade entre 9,9 e 16,6 tha ${ }^{-1}$, em função do porta-enxerto foram para N, P, $\mathrm{K}, \mathrm{Ca}, \mathrm{Mg}$, respectivamente de 64,9; 19,0;156,9;45,8 e 12,66 $\mathrm{kg} \mathrm{ha}^{-1}$ quando enxertadas sobre o Paulsen ' 1103 ' e de 112,$8 ; 29,3 ; 260,8 ; 82,3$ e 26,0 $\mathrm{kg} \mathrm{ha}^{-1}$ quando enxertadas sobre o 'VR 043-43'.

Palavras-chave: Nutrição mineral. Vitis labrusca. 'VR 043-43'. Paulsen '1103'.

${ }^{1}$ Prof. Dr., Departamento de Ciências Agronômicas, Universidade Federal do Paraná, UFPR Setor Palotina, Palotina, PR, Brasil. E-mail: asato@ufpr.br

2 Prof. Dr., Departamento de Agronomia, Universidade Estadual do Centro-Oeste, UNICENTRO, Guarapuava, PR, Brasil. E-mail: rbotelho@unicentro.br

${ }^{3}$ Eng $^{\circ} \mathrm{Agr}^{\circ}$, Departamento de Agronomia, UNICENTRO, Guarapuava, PR, Brasil. E-mail: broettodoglas@gmail.com

${ }^{4}$ Eng $^{\text {O Agr }}$, M.e, Empresa de Pesquisa Agropecuária e Extensão Rural de Santa Catarina, EPAGRI, Lajeado Grande, SC, Brasil. E-mail: marchithiago@yahoo.com.br

${ }^{5}$ Eng $^{\mathrm{a}}$ Agr ${ }^{\mathrm{a}}$, Discente de Mestrado, Departamento de Agronomia, UNICENTRO, Guarapuava, PR, Brasil. E-mail: irescristina21@ hotmail.com

* Author for correspondence 


\section{Introduction}

Brazilian viticulture is an important farming sector, with 80,000 hectares of vineyards and a yearly production of 1.4 million tons of grapes. Approximately $46 \%$ of this total is destined for processing (wine and juice) and $54 \%$ for table grapes.

In world viticulture, the important species are Vitis labrusca L. and $V$. vinifera L., popularly known as American and European grapevines, respectively. In Brazil, both are found in commercial vineyards, although the American vines are much better adapted to the different production regions.

Among the different American grapevines cultivated in Brazil, cv. Early Isabella is worth mentioning; it is a spontaneous somatic mutation of the cv. Isabella with an average cycle 33 days shorter than its progenitor. This new cultivar extended the processing time for juice and wine, in addition to enabling two crops per year in some warmer regions. According to Camargo (2004), this cultivar presents reasonable resistance to diseases such as anthracnose (Elsinoe ampelina) and oidium (Uncicula necator); it is thus an interesting candidate for organic production, obtaining an adequate plant stability using allowed products such as Bordeaux mixture and lime sulfur.

Despite its excellent adaptation to Brazilian conditions, information about the cultivation of Early Isabella grapevines is scarce, including the rootstock compatibility essential for the proper development of vines. The rootstock Paulsen '1103' is an important cultivar widely used for cultivation in cold regions because it is vigorous, easily rooted, and offers some resistance to Fusarium oxysporum f. sp. Herbemontis (EMBRAPA, 2003). Another potential rootstock is 'VR 043-43', which exhibits high resistance to Fusarium spp., phylloxera (Daktulosphaira vitifoliae) and the ground-pearl aphid (Eurhizococcus brasiliensis) (ANDRADE et al., 1994) that causes serious damage in Brazilian vineyards.
Another factor that contributes to vineyard success is the nutritional status of the plants. According to Tecchio et al. (2011), the nutritional demands of grapevines significantly vary in terms of cultivar and rootstock function. During their productive phase, the vines' demand for nutrients are defined by the permanent parts responsible for the yearly increase of biomass and the exported parts (pruned canes, leaves and clusters) typically considered as the nutrient consumption of the vines. Despite of the number of recommendations for fertilizing in different Brazilian regions (TERRA et al., 2003; CQFS-RS/SC, 2004), no scientific research has been carried out for base fertilizing recommendations in the Midwestern region of Paraná State, Brazil. Moreover, there is a lack of information regarding organic systems and/or different rootstocks.

The amount of fertilizer to be applied depends on nutritional plant demands, nutrient availability in soil minerals and organic matter decomposition. Therefore, aiming to estimate the nutritional demand of grapevines is necessary to quantify plant reserves in the stem and roots, as well the amounts exported by leaves, canes and clusters (NEILSEN; NEILSEN, 2003).

Weinbaum et al. (2001) suggested that a mineral analysis of the entire plant with a biomass determination was the most appropriate method for estimating a plant's nutrient uptake pattern. Some studies using this principle have been previously performed to estimate nutrient uptake and distribution in apple trees (HAYNES; GOH, 1980), peach trees (STASSEN et al., 1981), grapevines (Vitis vinifera L.) (CONRADIE, 1981) and pear trees (QUARTIERI et al., 2002; STASSEN; NORTH, 2005).

In this context, this study evaluated the vegetative and productive development of 'Early Isabella' grapevines grafted on Paulsen '1103' and 'VR 043-43' in the Midwestern region of Paraná State, Brazil. 


\section{Materials and Methods}

The trial was carried out in an experimental vineyard located in Guarapuava, Paraná State, Brazil (2523'36" S 51 $27^{\circ}$ '19' W; and $1.120 \mathrm{~m}$ a.s.1.). The weather is classified as a subtropical mesothermal humid climate $(\mathrm{Cfb})$ without a dry season, with fresh summers and mild winters (IAPAR, 2010); the soil is classified as dystroferric Brown Latosols (EMBRAPA, 2006).

Grapevines were planted in September 2005; they were spaced $2.5 \times 1.0 \mathrm{~m}$ apart and arranged in a spurred cordon with a three-wire trellis and drip irrigation. The experimental design was organized in randomized blocks with two treatments (rootstocks: Paulsen '1103' and 'VR 043-43'), four replications and a three-plant experimental plot.

Based on a chemical analysis performed prior to planting, the soil fertility was corrected in the entire area through the application of gypsum equivalent to $4 \mathrm{t} \mathrm{ha}^{-1}$ (15\% humidity, calcium [Ca] $15 \%$, sulfur [SO ${ }_{4}$ ] 28\%, phosphorus [P2O4] 0.75\%, fluorine [F] $3.2 \%$, silicon $\left[\mathrm{SiO}_{2}\right] 3.0 \%$ ), natural Arad phosphate equivalent to $1 \mathrm{t} \mathrm{ha}^{-1}\left(33 \% \mathrm{P}_{2} \mathrm{O}_{5}, 9 \%\right.$ in citric acid), and potassium sulfate equivalent to $300 \mathrm{~kg} \mathrm{ha}^{-1}$ $\left(50 \% \mathrm{~K}_{2} \mathrm{O}, 45 \% \mathrm{SO}_{4}\right)$. In addition, cattle manure equivalent to $10 \mathrm{t} \mathrm{ha}^{-1}$ was applied to the planting furrow. The vineyard was organically managed for five years (Brazilian Instruction Rules $n^{\circ}$ 6.323), (MAPA, 2014) using the following nutrient sources: wood ashes, cattle manure, natural phosphates, rock dust and green manures (vetch [vicia villosa roth], jack bean [canavalia ensiformis], guandu [cajanus cajan], black oat [Avena strigosa]), biofertilizers, calcitic lime and gypsum.

In the winter of 2010, five years after planting, one plant per experimental plot was removed via soil excavation and divided in three parts: roots, stem and canes. The remaining vines in the field were used to estimate production by cluster harvest at 102 days after flowering, on 12 January 2011, when the grapes attained a minimum soluble solid content of $16 \%$.

The samples were dried at $65^{\circ} \mathrm{C}$ to a constant weight to determine the nitrogen $(\mathrm{N})$, phosphorus $(\mathrm{P})$, potassium $(\mathrm{K})$, calcium $(\mathrm{Ca})$ and magnesium $(\mathrm{Mg})$ contents. The dry mass was subsequently measured with a precision balance and the samples were ground in a Willey mill. A chemical analysis was performed according to the methodology proposed by Silva (2009). The P content $\left(\mathrm{g} \mathrm{kg}^{-1}\right)$ was determined through spectrophotometry, the $\mathrm{K}$ content $\left(\mathrm{g} \mathrm{kg}^{-1}\right)$ through flame photometry, and the $\mathrm{Ca}$ and $\mathrm{Mg}\left(\mathrm{g} \mathrm{kg}^{-1}\right)$ contents through atomic absorption spectrophotometry.

Dry mass and nutrient content data were used to determine the nutrient amount immobilized in each part (roots, stem and canes) and exported to clusters (Nutrient amount $=$ dry mass $\mathrm{x}$ nutrient content). To estimate amounts per hectare, a planting density of 4,000 vines ha $^{-1}$ was considered.

The results were submitted to a variance analysis and the means were compared via Tukey's test ( $p$ $\leq 0.05)$ with the computational statistical package Sisvar 5.0 (FERREIRA, 2000).

\section{Results and Discussion}

The 'Early Isabella' grapevines grafted on the 'VR 043-43' rootstock presented significantly higher dry mass for all parts (canes, roots, stem and clusters) and consequently, a higher total dry mass (Table 1) than the plants grafted on Paulsen '1103'. Moreover, the vines grafted on 'VR 043-43' rootstock obtained a higher yield. 
Table 1. Chemical characteristics of soil vineyard before planting with 'Early Isabella' grapevines grafted on 'VR 043-43'and Paulsen '1103’ rootstocks. Guarapuava-PR, 2010.

\begin{tabular}{|c|c|c|c|c|c|c|c|c|c|c|}
\hline \multirow{2}{*}{$\begin{array}{c}\text { Depth } \\
\mathrm{cm}\end{array}$} & \multirow{2}{*}{$\underset{\mathrm{CH}}{\mathrm{pHCl}}$} & \multirow{2}{*}{$\begin{array}{l}\text { O. M. } \\
\mathrm{g} / \mathrm{dm}^{3}\end{array}$} & \multirow{2}{*}{$\begin{array}{l}\mathrm{P}_{\text {melich }} \\
\mathrm{mg} / \mathrm{dm}^{3}\end{array}$} & $\mathrm{~K}$ & $\mathrm{Ca}$ & $\mathrm{Mg}$ & $\mathrm{H}+\mathrm{Al}$ & SB & CTC & \multirow{2}{*}{$\mathrm{V} \%$} \\
\hline & & & & & & & $\mathrm{ol} / \mathrm{dm}^{3}$ & & & \\
\hline $0-20$ & 5.6 & 34.9 & 12.9 & 0.97 & 6.5 & 2.3 & 3.93 & 9.78 & 13.71 & 71.3 \\
\hline $20-40$ & 5.5 & 36.2 & 6.7 & 0.93 & 4.9 & 2.0 & 3.67 & 7.83 & 11.51 & 68.1 \\
\hline
\end{tabular}

The higher plants dry mass and yield of vines grafted on 'VR 043-43' rootstock could be explained by canopy-rootstock affinity and the edaphoclimatic conditions of each region (KUHN et al., 1996). Sato et al. (2008) verified higher growth rates of 'Isabella' and 'Rubea' when grafted on IAC-766 'Campinas' rootstock than those of ' $420-\mathrm{A}^{\prime}$ ' in the Northern region of Paraná State.

The effects of rootstock were also studied by Brighenti et al. (2010) in the State of Santa Catarina, where 'Cabernet Sauvignon' grapevines presented higher fresh mass of pruning canes when grafted on Paulsen '1103' rootstock than that of 'Couderc 3309' and '101-14 Mgt'. Similarly, Broetto et al. (2011) reported higher vegetative growth of different American grapevine cultivars when grafted on 'VR 043-43' rootstock.

Another important consideration is the higher tolerance of 'VR 043-43' rootstock to the groundpearl aphid (Eurhizococcus brasiliensis) in relation to Paulsen '1103' (BOTTON et al., 2004). The use of this rootstock could be a suitable option for grapevines managed organically in areas known to contain this pest. This rootstock allows good growth conditions, without grapevines decline, normally noted in other rootstocks. Broetto et al. (2011) noted a lower infestation level of ground-pearl in grapevines grafted on 'VR 043-43' rootstock than that on Paulsen '1103' and consequently, a higher vegetative growth. Moreover, a higher root dry mass in vines grafted on 'VR 043-43' (table 2) increases water and nutrient uptake and aids in the storage of resources, thus contributing to adequate vegetative growth.

The results on the immobilization of macronutrients $\mathrm{N}, \mathrm{P}, \mathrm{K}, \mathrm{Ca}$ and $\mathrm{Mg}$ in the different parts of 'Early Isabella' grapevines grafted on Paulsen '1103' and 'VR 043-43' are presented in Table 3. No differences between rootstocks were verified for nutrient immobilization in the canes. As for other nutrients, grapevines grafted on 'VR 043$43^{\prime}$ presented higher amounts than those grafted on Paulsen '1103'.

Table 2. Dry mass and yield of grapevines cv. Isabel Precoce grafted on Paulsen '1103' and 'VR 043-43'rootstocks, managed organically. Guarapuava, PR, 2010.

\begin{tabular}{|c|c|c|c|c|c|c|}
\hline \multirow{2}{*}{ rootstock } & \multicolumn{5}{|c|}{ dry mass $\left(\mathrm{kg} \mathrm{plant}^{-1}\right)$} & \multirow{2}{*}{ Yield $\left(\mathrm{t} \mathrm{ha} \mathbf{h}^{-1}\right)$} \\
\hline & cane & roots & stem & Cluster & Total & \\
\hline Paulsen '1103' & $0.66 \mathrm{~b}$ & $0.37 \mathrm{~b}$ & $0.67 \mathrm{~b}$ & $0.37 \mathrm{~b}$ & $2.33 \mathrm{~b}$ & $9.9 \mathrm{~b}$ \\
\hline 'VR 043-43' & $0.90 \mathrm{a}$ & $0.57 \mathrm{a}$ & $0.76 \mathrm{a}$ & $0.61 \mathrm{a}$ & $2.60 \mathrm{a}$ & $16.3 \mathrm{a}$ \\
\hline DMS & 0.16 & 0.19 & 0.08 & 0.38 & 0.24 & 2.7 \\
\hline CV (\%) & 9.3 & 18.4 & 6.6 & 31.5 & 5.6 & 12.0 \\
\hline
\end{tabular}

Means followed by the same letter in column no differ by Tukey's test ( $\mathrm{p} \leq 0.05) .4,000$ plants/hectare. 
Table 3. Nutrient immobilization in canes, roots and stem of grapevines cv. Early Isabella grafted on Paulsen '1103' and 'VR 043-43' rootstocks, managed organically. Guarapuava, PR, 2010.

\begin{tabular}{|c|c|c|c|c|c|}
\hline \multirow{2}{*}{ Plant parts } & \multirow{2}{*}{ Nutrient } & \multicolumn{2}{|c|}{ Immobilization $\left(\mathrm{kg} \mathrm{ha}^{-1}\right)$} & \multirow{2}{*}{ LSD } & \multirow{2}{*}{ CV $(\%)$} \\
\hline & & Paulsen '1103' & 'VR 043-43' & & \\
\hline \multirow{5}{*}{ Canes } & $\mathrm{N}$ & $4.1 \mathrm{a}$ & $5.0 \mathrm{a}$ & 1.06 & 13.9 \\
\hline & $\mathrm{P}$ & $3.4 \mathrm{~b}$ & $4.3 \mathrm{a}$ & 0.37 & 4.3 \\
\hline & $\mathrm{K}$ & $11.5 \mathrm{~b}$ & $16.4 \mathrm{a}$ & 1.81 & 5.8 \\
\hline & $\mathrm{Ca}$ & $15.4 \mathrm{~b}$ & $21.2 \mathrm{a}$ & 1.51 & 3.7 \\
\hline & $\mathrm{Mg}$ & $2.9 \mathrm{~b}$ & $4.5 \mathrm{a}$ & 0.42 & 5.0 \\
\hline \multirow{5}{*}{ Roots } & $\mathrm{N}$ & $10.8 \mathrm{a}$ & $8.6 \mathrm{a}$ & 2.4 & 15.0 \\
\hline & $\mathrm{P}$ & $4.2 \mathrm{a}$ & $5.8 \mathrm{a}$ & 2.7 & 24.4 \\
\hline & $\mathrm{K}$ & $5.1 \mathrm{a}$ & $8.7 \mathrm{a}$ & 5.1 & 32.6 \\
\hline & $\mathrm{Ca}$ & $11.8 \mathrm{~b}$ & $22.1 \mathrm{a}$ & 3.2 & 8.3 \\
\hline & $\mathrm{Mg}$ & $3.0 \mathrm{~b}$ & $4.6 \mathrm{a}$ & 0.8 & 9.9 \\
\hline \multirow{5}{*}{ Stem } & $\mathrm{N}$ & $2.8 \mathrm{a}$ & $3.0 \mathrm{a}$ & 0.31 & 6.5 \\
\hline & $P$ & $1.6 \mathrm{a}$ & $1.8 \mathrm{a}$ & 0.57 & 14.6 \\
\hline & $\mathrm{K}$ & $4.7 \mathrm{a}$ & $5.3 \mathrm{a}$ & 3.08 & 27.3 \\
\hline & $\mathrm{Ca}$ & $13.8 \mathrm{a}$ & $17.2 \mathrm{a}$ & 4.22 & 12.1 \\
\hline & $\mathrm{Mg}$ & $2.5 \mathrm{~b}$ & $3.0 \mathrm{a}$ & 0.50 & 8.2 \\
\hline
\end{tabular}

Means followed by the same letter in column no differ by Tukey's test $(\mathrm{p} \leq 0.05) .4,000$ plants/hectare.

The levels of nutrients immobilized in grapevine canes is an important factor in defining the fertilization criteria in certain cycles, particularly when considering that canes are normally removed after pruning for sanitary reasons. Therefore, nutrient replenishment is necessary to maintain a satisfactory availability of nutrients in the vineyard (TECCHIO et al., 2011). Moreover, nutrient extraction varies according to canopy, rootstock and region. According to Giovannini et al. (2001), canes from 'Cabernet Sauvignon' grapevines grafted on 'Kober 5BB' extracted $14 \mathrm{~kg}$ of $\mathrm{N}$ per hectare on average-much higher than the amounts observed in this research.

As for nutrient immobilization in the roots and stem, the levels of $\mathrm{Ca}$ and $\mathrm{Mg}$ in the roots and $\mathrm{Mg}$ in the stem were significantly higher in vines grafted on 'VR 043-43', although no differences were verified for the remaining nutrients. The higher nutrient immobilization levels in vines grafted on 'VR 043-43' can be directly related to the greater root dry mass and consequently higher vegetative growth.
Similarly, Albuquerque and Dechen (2000) also reported that biomass production was directly related to the amount of nutrient accumulation $(\mathrm{N}, \mathrm{P}$, $\mathrm{K}$ and $\mathrm{Ca}$ ), and grapevines grafted on 'VR 043-43' presented the highest accumulation of dry matter in all plant parts.

According to Mullins et al. (2000) the quantities of nutrients in the structural parts (stem and canes) of grapevines are substantial. The levels of $\mathrm{N}$ and $\mathrm{K}$ in roots, stems and canes in 'Chenin Blanc' grapevines spaced at $2.44 \times 2.44 \mathrm{~m}(1,680$ plants per ha ${ }^{-1}$ ) were equivalent to 215 and $124 \mathrm{~kg} \mathrm{ha}^{-1}$, respectively. The mineral nutrients in the permanent parts of the grapevines can be remobilized to supply demands for growth in the new cycle, including new root growth, when vine uptake is insufficient.

Table 4 presents the nutrient quantities exported by clusters. The levels of $\mathrm{N}, \mathrm{Ca}$ and $\mathrm{Mg}$ were highest for grapevines grafted on 'VR 043-43' rootstock, whereas no significant differences were verified in the rootstocks for other nutrients. The 'VR 043-43' rootstock promoted higher nutrient reserves in permanent parts and a greater root 
system. Therefore, despite the higher yield of 'Early Isabella' grapevines grafted on this rootstock, the nutrient exportation per unit of cluster weight was also higher for other elements (N, Ca, Mg).

Tecchio et al. (2011) also reported differences in nutrient content in 'Niagara Rosada' grapevine clusters as a function of rootstock. In vines grafted on 'IAC 571-6' rootstock, the $\mathrm{N}$ content in the clusters was $7.1 \mathrm{~kg} \mathrm{t}^{-1}$, whereas for plants grafted on IAC 572 'Tropical' and IAC 766 'Campinas' the content was $8.7 \mathrm{~kg} \mathrm{t}^{-1}$. As for $\mathrm{K}$, the authors observed higher content in grapes from vines grafted on IAC 572 'Jales' $\left(23,1 \mathrm{~kg} \mathrm{t}^{-1}\right)$ than in plants grafted on 'IAC 571-6' (18,1 $\left.\mathrm{kg} \mathrm{t}^{-1}\right)$; no differences were noticed for the element P. In general, the nutrient levels exported by clusters of 'Early Isabella' grapevines was lower than those reported by Tecchio et al. (2011) in 'Niagara Rosada' grapevines, grafted on different rootstocks, probably due to the genetic characteristics of each cultivar and different climatic conditions.

Table 4. Nutrient exportation by clusters of grapevines cv. Early Isabella grafted on Paulsen '1103' and 'VR 043-43', managed organically. Guarapuava, PR, 2010.

\begin{tabular}{|c|c|c|c|c|}
\hline \multirow{2}{*}{ Nutrient } & \multicolumn{2}{|c|}{ Exportation $\left(\mathrm{Kg} \mathrm{t}^{-1}\right)$} & \multirow{2}{*}{ LSD } & \multirow{2}{*}{ CV $(\%)$} \\
\hline & Paulsen '1103' & 'VR 043-43' & & \\
\hline $\mathbf{N}$ & $4.74 \mathrm{~b}$ & $5.90 \mathrm{a}$ & 1.11 & 12.6 \\
\hline $\mathbf{P}$ & $0.99 \mathrm{a}$ & $1.04 \mathrm{a}$ & 0.05 & 2.5 \\
\hline $\mathbf{K}$ & $13.78 \mathrm{a}$ & $13.87 \mathrm{a}$ & 1.52 & 4.9 \\
\hline $\mathrm{Ca}$ & $0.50 \mathrm{~b}$ & $1.32 \mathrm{a}$ & 0.24 & 15.6 \\
\hline Mg & $0.44 \mathrm{~b}$ & $0.84 \mathrm{a}$ & 0.02 & 1.6 \\
\hline
\end{tabular}

Means followed by the same letter in column no differ by Tukey's test $(p \leq 0.05) .4,000$ plants/hectare.

However, according to a review presented by Mullins et al. (2000), many studies of nutrient exportation by clusters of different grapevine cultivars showed lower amounts compared to our results, with 1.46, 0.28, 2.47, 0.50 and $0.40 \mathrm{k} \mathrm{t}^{-1}$, for $\mathrm{N}, \mathrm{P}, \mathrm{K}, \mathrm{Ca}$ e $\mathrm{Mg}$, respectively

Differences between rootstocks were verified for nutrient extraction order in 'Early Isabella' grapevines. Plants grafted on 'VR 043-43' rootstock presented the following extraction order: $\mathrm{K}>\mathrm{N}>\mathrm{Ca}>\mathrm{P}>\mathrm{Mg}$; while for Paulsen '1103' the decreasing order was $\mathrm{K}>\mathrm{N}>\mathrm{P}>\mathrm{Mg}>\mathrm{Ca}$. The results found in this research by 'Early Isabella' grapevines grafted on 'VR 043-43' are similar to those verified by Tecchio et al. (2011) in 'Niagara Rosada' over different rootstocks in Votuporanga-SP, where the nutrient extraction by clusters showed the following decreasing order similar to all rootstocks: $\mathrm{K}>\mathrm{N}>\mathrm{Ca}>\mathrm{P}>\mathrm{Mg}$.
Independent of the rootstock, $\mathrm{K}$ was the most abundant nutrient exported by clusters. According to Hudina and Stampar (2002), this element is essential to cluster qualities such as grape size, soluble solid content, organic acids and flavor. Therefore, knowledge of nutrient demand by the plants is paramount for adequate replenishment through fertilization (TAGLIAVANI et al., 1996).

In general, the results found in this trial are useful in determining the nutrient demands of 'Early Isabella' grapevines grafted on Paulsen '1103' and 'VR 043-43' rootstocks managed in an organic system in the Midwestern region of Paraná State. This important information can aid fertilization programs in commercial vineyards. 


\section{Conclusions}

'Early Isabella' grapevines presented greater dry mass and yield when grafted on 'VR 043-43' rootstock and higher nutrient immobilization of $\mathrm{P}, \mathrm{K}, \mathrm{Ca}$ and $\mathrm{Mg}$ in canes; $\mathrm{Ca}$ and $\mathrm{Mg}$ levels in roots; and Mg levels in stems than Paulsen '1103' rootstock.

The nutrient immobilization and exportation levels of Early Isabella grapevines were 64.9, 19.0, 156.9, 45.8 and $12.7 \mathrm{~kg} \mathrm{ha}^{-1}$ for N, P, K, Ca, $\mathrm{Mg}$, respectively, when grafted on Paulsen '1103' rootstock and 112.8, 29.3, 260.8, 82.3 and $26,0 \mathrm{~kg}$ $\mathrm{ha}^{-1}$ when grafted on 'VR 043-43'.

\section{References}

ALBUQUERQUE, T. C. S.; DECHEN, A. R. Absorção de macronutrientes por porta-enxertos e cultivares de videira em hidroponia. Scientia Agricola, Piracicaba, v. 57, n. 1, p. 135-139, 2000.

ANDRADE, E. R. de; DAL BÓ, M. A.; SCHUCK, E. Avaliação da resistência de germoplasma de videira ao Fusarium oxysporum f. sp. herbemontis. Revista Brasileira de Fruticultura, Jaboticabal, v. 16, n. 1, p. 139-145, 1994.

BOTTON, M.; HICKEL, E. R.; SORIA, S. J.; SCHUCK, E. Pérola-da-terra. In: SALVADORI, J. R.; ÁVILA, C. J.; SILVA. M. T. B. (Org.). Pragas de solo no Brasil. Passo Fundo: Embrapa, 2004. p. 457-476.

BRIGHENTI, A. F.; RUFATO, L.; KRETZSCHMAR, A. A.; MADEIRA, F. C. Desponte dos ramos da videira e seu efeito na qualidade dos frutos de Merlot sobre porta-enxertos Paulsen 1103 e Couderc 3309. Revista Brasileira de Fruticultura, Jaboticabal, v. 32, n. 1, p. 1926, 2010.

BROETTO, D.; BAUMANN JUNIOR, O.; SATO, A. J.; BOTELHO, R. V. Desenvolvimento e ocorrência de pérola-da-terra em videiras rústicas e finas enxertadas sobre os porta-enxertos VR 043-43 e Paulsen 1103. Revista Brasileira de Fruticultura, Jaboticabal, p. 404410, 2011. Especial.

CAMARGO, U. A. Isabel precoce: alternativa para a vitivinicultura brasileira. Bento Gonçalves: Embrapa Uva e Vinho, 2004. 4 p. (Comunicado técnico, 54).

COMISSÃO DE QUÍMICA E FERTILIDADE DO SOLO - CQFS-RS/SC. Manual de adubação e calagem para os Estados do Rio Grande do Sul e de Santa Catarina. $10^{\text {th }}$ ed. Porto Alegre: SBCS - Núcleo Regional Sul/UFRGS, 2004. 400 p.

CONRADIE, W. J. Seasonal uptake of nutrients by Chenin Blanc in sand culture: II. Phosphorus, potassium, calcium and magnesium. South African Journal of Enology and Viticulture, Deensig, v. 2, n. 1, p. 7-13, 1981.

EMPRESA BRASILEIRA DE PESQUISA AGROPECUÁRIA - EMBRAPA. EMBRAPA Uva e Vinho. Uvas viníferas para processamento em regiões de clima temperado. Sistema de produção. Brasília: Embrapa, jul. 2003. Disponível em: $<$ http:// sistemasdeproducao.cnptia.embrapa.br/FontesHTML/ $\mathrm{Uva} /$ UvasViniferasRegioesClimaTemperado/cultivar. htm>. Acesso em: 20 maio 2014.

Centro Nacional de Pesquisa de Solos. Sistema brasileiro de classificação de solos. 2. ed. Rio de Janeiro: Embrapa Solos, 2006.

FERREIRA, D. F. Análises estatísticas por meio Sisvar para Windows versão 4.0. In: REUNIÃO ANUAL DA SOCIEDADE INTERNACIONAL DE BIOMETRIA, 45., 2000. São Carlos. Anais... São Carlos: UFSCar, 2000. p. 255-258.

GIOVANNINI, E.; FRÁGUAS, J. C.; MIELE, A.; BARRADAS, C. I. N. Extração de nutrientes pela videira cv. Cabernet Sauvignon na Serra Gaúcha. Pesquisa Agropecuária Gaúcha, Porto Alegre, v. 7, n. 1, p. 27-39, 2001.

HAYNES, R. J.; GOH, K. Distribution and budget of nutrients in a commercial apple orchard. Plant and Soil, Crawley, v. 56, n. 3, p. 445-457, 1980.

HUDINA, M.; STAMPAR, F. Effect of phosphorus and potassium foliar fertilization on fruit quality of pears. Acta Horticulturae, Lueven, v. 594, n. 1, p. 487-493, 2002.

INSTITUTO AGRONÔMICO DO PARANÁ - IAPAR. Cartas climáticas do Paraná. Londrina : IAPAR, 2000. CD-ROM.

KUHN, G. B.; LOVATEL, J. L.; PREZOTTO, O. P.; RIVALDO, O. F.; MANDELLI, F.; SÔNEGO, O. R. $O$ cultivo da videira: informações básicas. 2. ed. Bento Gonçalves: Embrapa-CNPUV, 1996. (Circular técnica, 10).

MINISTÉRIO DA AGRICULTURA, PECUÁRIA E ABASTECIMENTO - MAPA. Legislação. Brasília: MAPA, 2014. Disponível em: <http://extranet. agricultura.gov.br/sislegis/action/detalhaAto.do?meth od $=$ consultarLegislacaoFederal $>$. Acesso em: 20 maio 2014. 
MULLINS, M. G.; BOUQUET, A.; WILLIAMS, L. E. Biology of the grapevine. Cambridge: University Press, 2000. 239 p.

NEILSEN, G. H.; NEILSEN, D. Nutritional requirements of apple. In: FERREE, D. C.; WARRINGTON, I. J. (Ed.). Apples: botany, production and uses. Cambridge: CAB International, 2003. p. 267-301.

QUARTIERI, M.; MILLARD, P.; TAGLIAVINI, M. Storage and remobilisation of nitrogen by pear (Pyrus communis L.) trees as affected by timing of $\mathrm{N}$ supply. European Journal of Agronomy, Polheim, v. 17, n. 2, 105-110, 2002.

SATO, A. J.; SANTOS, C. E.; BERTOLUCCI, R.; CARIELO, M.; GUIRAUD, M. C.; ROBERTO, S. R. Fenologia e demanda térmica das videiras Isabel e Rubea sobre diferentes porta-enxertos na região Norte do Paraná. Semina: Ciências Agrárias, Londrina, v. 29, n. 1, p. 283-292, 2008.

SILVA, F. C. (Ed.). Manual de análises químicas de solos, plantas e fertilizantes. 2. ed. Brasília: Embrapa Informação Tecnológica. Rio de Janeiro: Embrapa Solos, 2009. $627 \mathrm{p}$.

STASSEN, P. J. C.; NORTH, M. S. Nutrient distribution and requirement of Forelle pear trees on two rootstocks. Acta Horticulturae, Leiden, v. 671, n. 1, p. 493-500, 2005.
STASSEN, P. J. C.; STINDT, H. W.; STRYDOM, D. K.; TERBLANCHE, J. H. Seasonal changes in nitrogen fraction of young Kakamas peach trees. Agroplantae, Pretoria, v. 13, n. 1, p. 47-55, 1981.

TAGLIAVANI, M.; STEFFENS, D.; PELLICONI, F. La carenza di potassio nei vigneti della Romagna. Vignevini, Bologna, v. 23, n. 1, p. 41-46, 1996.

TECCHIO, M. A.; TEIXEIRA, L. A. J.; TERRA, M. M.; MOURA, M. F.; PAIOLI-PIRES, E. J. Extração de nutrientes pela videira Niagara Rosada enxertada em diferentes porta-enxertos. Revista Brasileira de Fruticultura, Jaboticabal, p. 736-742, 2011. Especial.

TERRA, M. M.; PIRES, E. J. P.; POMMER, C. V.; BOTELHO, R. V. Produtividade da cultivar de uva de mesa Niagara Rosada sobre diferentes porta-enxertos, em Monte Alegre do Sul - SP. Revista Brasileira de Fruticultura, Jaboticabal, v. 25, n. 3, p. 549-551, 2003.

WEINBAUM, S. A. Necessity for whole tree excavations in determining patterns and magnitude of macronutrient uptake by mature deciduous fruit trees. Acta Horticulturae, Leiden, v. 564, n. 1, p. 41-49, 2001. 